'llu. Revista de Ciencias de las Religiones

ISSN: $1135-4712$

http://dx.doi.org/10.5209/ILUR.61026

\title{
Temor y temblor. Los simbolismos del miedo en la cultura pentecostal chilena
}

\author{
Miguel Ángel Mansilla'; Wilson Muñoz ${ }^{2}$; Carlos Piñones Rivera ${ }^{3}$
}

Recibido: 15 de diciembre de 2016 / Aceptado: 7 de diciembre 2017

Resumen. El objetivo de este artículo es analizar las semánticas que ha adquirido el simbolismo del miedo en la cultura pentecostal chilena. A partir de la revisión y análisis de información bibliográfica, mostraremos cómo se manifiesta la figura del miedo en las imágenes del infierno, el Diablo y Dios. Luego entregamos una interpretación sobre la peculiaridad simbólica del miedo, el cual operaría como una especie de símbolo dominante del pentecostalismo, no solo por ser uno de los símbolos más gravitantes de la cultura pentecostal, sino también porque su polisemia facilitaría la captura de atención de los creyentes. Esto le permitiría condensar una serie de significados paradójicos y tematizar la distinción entre lo trascendente e inmanente, facilitando así la difusión de una imagen del miedo con un claro sentido deontológico y aleccionador a sus creyentes, para lo cual utilizaría recursos propios del contexto histórico, social y cultural. Palabras clave: miedo, simbolismo, pentecostalismo, Chile.

\section{[en] Fear and tremor. The symbolisms of fear in the Chilean Pentecostal culture}

\begin{abstract}
The aim of this article is to analyse the semantics that has acquired the fear's symbolism in the culture of Chilean Pentecostalism. By means of the revision and analysis of bibliographic information, we will show how the figure of fear is revealed in the images of hell, the Devil and God. Then we will provide an interpretation of the symbolic peculiarity of fear, which seems to operate as a kind of master symbol of Pentecostalism, not only because it is one of the most important symbols of this culture, but because its polysemy helps to attract the attention of the believers. This would allow it to gather a wide range of paradoxical meanings and to thematize the distinction between transcendence and immanence, and also to facilitate the transmission of one image of fear with a clear deontological and exemplary function for its believers. In order to achieve this, the symbol of fear uses resources from the historical, social and cultural context.
\end{abstract}

Keywords: fear, symbolism, Pentecostalism, Chile.

Sumario. 1. Introducción. 2. El miedo al infierno. 3. El miedo al Diablo. 4. El miedo a Dios. 5. Reflexiones finales. 6. Bibliografía. 6.1. Fuentes primarias. 6.2. Fuentes secundarias.

1 Instituto de Estudios Internacionales (INTE), Universidad Arturo Prat (UNAP-Chile).

Correo electrónico: mansilla.miguel@gmail.com

2 Laboratoire d'Anthropologie Sociale (LAS), Collège de France/EHESS/CNRS/PSL Research University (Francia). Research Institute of Sociology of Religion (ISOR), Universitat Autònoma de Barcelona (UAB-España). Facultad de Educación y Humanidades, Universidad de Tarapacá (UTA-Chile).

Correo electrónico: wilsonsocio@gmail.com

3 Instituto de Estudios Internacionales (INTE), Universidad Arturo Prat (UNAP-Chile). Correo electrónico: carlospinonesrivera@gmail.com 
Cómo citar: Mansilla, M. A., Muñoz, W., Piñores Rivera, C. (2018), Temor y temblor. Los simbolismos del miedo en la cultura pentecostal chilena, en 'Ilu. Revista de Ciencias de las Religiones 23, 175-190.

\section{Introducción}

El pentecostalismo es uno de los movimientos religiosos más significativos de Chile 4 . Desde sus inicios se caracterizó por ser un movimiento endógeno y que creció fuertemente entre los sectores más desaventajados de la población ${ }^{5}$. Dotado de un discurso fuertemente conversionista y especialmente crítico con el orden social y moral imperante, su semántica se cargó de un simbolismo polisémico basado en la devaluación de la vida terrena, en contraposición con el engrandecimiento de la vida ultraterrena.

En este escenario, algunas de las figuras simbólicas más importantes utilizadas durante la expansión del pentecostalismo fueron aquellas relacionadas con el mie$\mathrm{do}^{6}$. Tanto la literatura como la evidencia empírica nos sorprende por la frecuente presencia de la simbólica del miedo en testimonios, predicaciones, oraciones y una serie de otros dispositivos discursivos que han utilizado los pentecostales para dar a conocer la palabra de Dios, incitar a la conversión y promover un discurso deontológico entre sus filas ${ }^{7}$. Además, históricamente los simbolismos del miedo se han manifestado en distintas figuras semánticas, siendo predominante su presencia en figuras como el infierno, el diablo y Dios (entre muchas otras), convirtiéndose así en uno de los símbolos más importantes dentro del movimiento.

No sostenemos que el pentecostalismo sea un movimiento religioso esencialmente productor o generador de miedo, sino que más bien se caracterizaría por hacer uso de los miedos disponibles culturalmente a la hora de obtener una mayor eficacia simbólica en sus discursos, especialmente en aquellos de carácter conversionista. Es en este sentido que el miedo es una construcción cultural.

La figura del miedo también está situada socialmente. Recordemos que los grupos sociales que los pentecostales adoctrinaron fueron hombres y mujeres que habían migrado desde el campo a la ciudad, situados mayoritariamente en las capas más bajas de la sociedad. Estos grupos "necesitaban" ser socializados en un ethos pentecostal vinculado al trabajo fabril, la prohibición frente al alcohol, la regulación de la natalidad sujeta al matrimonio monogámico, la asistencia religiosa, etc., estableciendo con ello un claro control social. Para llevar a cabo este ejercicio, las horribles figuras del diablo y del infierno fueron potenciados culturalmente y se convirtieron en símbolos eficaces, de manera que el sólo hecho de mencionarlos o imaginarlos intimidaría potencialmente a cualquier transgresor.

La figura del miedo también se encuentra situada históricamente ${ }^{8}$. Si nos retrotraemos a los orígenes del pentecostalismo, resulta claro que los líderes pentecostales necesitaban crecer y expandirse a través de todo Chile, entre otras cosas para evidenciar la legitimidad del movimiento carismático frente al protestantismo, su competencia inmediata. No obstante, rápidamente florecería la competencia intradiscursiva entre las mismas filas del pentecostalismo. Sin embargo, su mayor compe-

\footnotetext{
Cleary \& Sepúlveda 1997.

D’Epinay 1968; Mansilla 2007.

Mansilla 2016.

Bahamondes y Marín 2013.

En este sentido es conocido el texto Delumeuau 2005.
} 
tencia religiosa era y sigue siendo el catolicismo popular, al cual necesitaban deslegitimar e invalidar.

Junto a su crecimiento y expansión inicial, el pentecostalismo convirtió a la predicación en una responsabilidad de carácter individual, siendo elevada, primero a la categoría de "trabajo". Luego fue erigida al más alto honor de trabajo. Así, el ethos del trabajo pentecostal se constituyó en una dualidad espiritual/material: el trabajo espiritual producía almas y el trabajo material producía dinero, necesario este último para mantener a las almas. El mayor pecado entre los pentecostales era no trabajar y/o realizar cualquier actividad que lo impidiera (ocio, desidia, flojera, vicios, etc.). Por ejemplo, es común encontrar testimonios donde se señala que las personas se iban al infierno por flojera, por beber, pero fundamentalmente por no predicar (trabajo espiritual). De hecho, el mayor castigo en el infierno estaba reservado para los predicadores que no predicaban ${ }^{9}$. En este escenario, el miedo se constituyó en la fusta que espoleaba y controlaba a los convertidos urbanos populares, especialmente durante los inicios del pentecostalismo.

Si bien la figura del miedo ha sido analizada en términos generales dentro de la literatura especializada del pentecostalismo chileno ${ }^{10}$, desconocemos cómo se ha manifestado este dispositivo religioso-cultural de manera pormenorizada y cuál ha sido su uso simbólico. El objetivo de este artículo es analizar las semánticas que ha adquirido el simbolismo del miedo en la cultura pentecostal chilena. A partir de la revisión y análisis de información bibliográfica, mostraremos cómo se manifiesta la figura del miedo en las imágenes del infierno, el Diablo y Dios. Luego entregamos una interpretación sobre la peculiaridad simbólica del miedo, el cual operaría como una especie de símbolo dominante ${ }^{11}$ del pentecostalismo chileno, no solo por ser uno de los símbolos más gravitantes de la cultura pentecostal, sino también porque su polisemia facilitaría la captura de atención de los creyentes. Esto le permitiría condensar una serie de significados paradójicos y tematizar y anatematizar la distinción entre lo trascendente e inmanente, facilitando así la difusión de una imagen del miedo con un claro sentido deontológico y aleccionador a sus creyentes, para lo cual utilizaría recursos propios del contexto histórico, social y cultural.

En términos metodológicos realizamos fundamentalmente un análisis sustentado en la revisión de fuentes documentales. Utilizamos la revista Chile Pentecostal, un periódico perteneciente al movimiento pentecostal desde 1910 hasta el año 1926, y que desde desde el año 1927 pasa a llamar Fuego de Pentecostés. No obstante, en el año 1933 se produce el primer cisma pentecostal chileno entre Iglesia Metodista Pentecostal de Chile (IMP) y la Iglesia Evangélica Pentecostal de Chile (IEP), esta última se quedará con la Revista Fuego de Pentecostés y posteriormente la IMP revivirá la Revista Chile Pentecostal. Ambas revista contienen las misma estructura de publicaciones, relatos, testimonios, direcciones de templos, etc. No obstante la Fuego de Pentecostés será la revista más estable y antigua del pentecostalismo chileno y de ahí nos sustentamos para desarrollar este artículo. No citamos las fuentes porque son muy extensas y decsriptivas por tratarse de testimonios y relatos de vidas ${ }^{12}$. Para el examen

\footnotetext{
Mansilla 2016.

Canton 2009; Mansilla 2009; Marín 2010; Bahamondes y Marín 2013; Mansilla 2013.

Turner 1973.

12 Para más detalle sobre los relatos y testimonios sobre el miedo a Dios, el Infierno el diablo y otros sujetos y obejtos de miedo al libro de M. Mansilla. La buena muerte. La cultura del morir en el pentecostalismo. RILUNAP, Santiago, Chile. 2016.
} 
de las representaciones utilizamos la técnica de análisis de contenido cualitativo. Por un lado, la idea es sobrepasar la interpretación del contenido manifiesto (análisis de contenido cuantitativo) del material analizado y profundizar en su contenido latente. Así, el análisis de los contenidos vinculados a los contextos «se convierte en trabajo de des-ocultación o re-velación de la expresión, donde ante todo interesa indagar sobre lo escondido, lo latente [...] de todo mensaje» ${ }^{13}$. Por otro lado, es necesario vincular este contenido con el contexto cultural donde se desarrolla el mensaje, pues de lo contrario no se podría entender el contenido de los datos recopilados. Para ello se necesita comprender la gama de conceptos y símbolos religiosos a la que recurren los pentecostales para referirse a los sujetos, objetos y espacios de miedo.

\section{EI miedo al infierno}

La tradición cristiana ha representado al infierno como el mundo del fuego, abrazado por la tiranía de la repetición y la desesperanza post mortem. Por ello, no es a la muerte terrenal en sí misma a lo que más temen los pentecostales, sino al destino al cual son arrojados tras este dramático acontecimiento. La muerte más execrable imaginada en el pentecostalismo es el infierno como destino, entendido como una entidad cosmológica donde lo más deleznable no es su fuego abrasador, sino la memoria y la conciencia de lo vivido, y su eterna repetición ${ }^{14}$. Así, lo peor de esta imagen nietzscheana del eterno retorno ${ }^{15}$ asociada al infierno, es la imposibilidad de la variación infinita. El infierno aparece entonces no solo como una configuración espaciotemporal situada en el más allá que albergará penosamente al infractor tras su muerte terrenal, sino también como aquel tiempo aplastante de la propia subjetividad del descreído que volverá sobre cada uno de sus actos vividos, autoflagelándose infinitamente y permaneciendo totalmente inerme ante este desenlace.

Si bien la vida terrenal puede ser entendida como infernal debido a las condiciones económicas y sociales experimentadas por extensas capas de la población en el contexto latinoamericano ${ }^{16}$, en la cultura pentecostal existe la esperanza última de que la muerte física pondría fin a este valle de lágrimas, otorgando el anhelado descanso celeste. No obstante, también existe la posibilidad de construir pequeños espacios y tiempos celestiales en el seno de las comunidades pentecostales. Aunque la vida terrenal se presente absolutamente descolorida frente a la vida ultraterrena, igualmente es fruto de esperanza y posibilidad. Así, el miedo iba de la mano con la esperanza.

Vemos entonces que en la cultura pentecostal existe una duplicación simbólica del infierno. En general, la vida terrenal (especialmente antes de la conversión) también es concebida de manera infernal, básicamente por dos motivos. Por un lado, porque el pasado religioso de los pentecostales convertidos era normalmente el mundo del catolicismo, la religión de origen. Así, concebir la vida anterior y al mundo como infernal era una forma de deslegitimación del catolicismo, pues era la competencia religiosa inmediata en los sectores populares, siendo considerado por los pentecostales como una creencia idolátrica (satánica) y cuyo destino era el infierno.

\footnotetext{
Piñuel 2002: 4

Mansilla 2016.

Nietzsche 1976.

Mansilla 2013.
} 
Por otro lado, recordemos también que la religión pentecostal sigue siendo predominantemente mayoritaria entre los sectores más desfavorecidos de la población. Para amplias capas de la sociedad subyugadas por las condiciones de miseria y pobreza del hogar, el barrio y el ámbito laboral, la sociedad aparece concebida como una entidad determinada y casi destinal, donde las barreras sociales se alzan como férreos círculos que reproducen la pobreza. En este escenario, pareciera ser que quien nace pobre, muere pobre, pese a que pueda volcarse fervientemente hacia el estudio o el trabajo, evidenciando así el conocido efecto Mateo ${ }^{17}$. Según palabras de los propios pentecostales, esto puede leerse así: al que tiene, se le dará más y tendrá en abundancia, pero a cualquiera que no tiene, aun lo que tiene se le quitará para dárselo al que tiene más.

La imagen del infierno reproduce entonces esta doble condición experimentada por las personas, la cual es generada por la miseria religiosa anterior y su condición de pobreza. Esto podía verse intensificada por la enfermedad, el desempleo o la pérdida prematura de algún familiar. Por ello es que los conversos daban testimonios de su vida anterior describiéndola como una vida infernal, dominada realmente por el demonio. De manera que el infierno no es una mera entelequia simbólica presente en la cultura pentecostal, sino que tenía una existencia real para los pobres. Muchas de las descripciones infernales del más allá aparecían más bien como proyecciones simbólicas del doble infierno experimentado en carne y hueso por los conversos, el cual parecía regir el mundo del más acá. Finalmente, el infierno es la muerte eterna, en contraposición al cielo que entrega una vida eterna. Es el espacio donde la explotación, la indiferencia y la opresión son absolutas: no hay derechos, ni justicia, ni libertad. De ahí que el terror que genere sirva como un dispositivo de control social, pues el infierno aparece figurado como el espacio de la doble muerte.

Esta concepción del infierno, tanto terrena como ultraterrena, está estrechamente vinculada con la concepción antropológica del pentecostalismo. El ser humano es concebido como un ser pérfido y disoluto en la cultura pentecostal, evocando con ello la clásica figura cristiana del ser caído, la cual fue exacerbada por la tradición protestante. Bajo esta imagen, el ser humano pareciera corromper todo lo bueno creado por Dios, transformando cotidianamente lo celestial en infernal, lo angélico en demoníaco, y los paraísos en yermos. Del ser humano, creatura divina caída, difícilmente puede emerger algún fruto bondadoso. Como correlato de esta ontología del pesimismo, la vida terrena aparece como un entorno que ha sido constituido para su muerte, donde el hombre es un ser que vive y se alimenta oprimiendo al otro, al más débil, pero temiendo u obedeciendo a su vez al más poderoso: es una bestia con los de abajo y una mascota con los de arriba. En este escenario, para controlar al ser humano se le debe recordar constantemente quién es: un ser miserable, perdido, una basura, un gusano. Natalia de Arancibia (esposa de Ceferino Arancibia, uno de los fundadores del pentecostalismo chileno), tuvo la oportunidad de dar su testimonio a través de la Revista Chile Pentecostal, describiendo al pentecostalismo como una religión de los pobres, señalando que "Dios está obrando... en los viles y miserables, en aquellos de los cuales hablaba Pablo, ser como basura, ser la hez del mundo, pero imitadores de Dios como hijos amados" ${ }^{\prime 1}$. Este relato fundacional rubricará esta identidad nadista y vacua.

Merton 1968; Bunge 2002.

18 Chile Pentecostal 1910, 2-3. 
El ser humano es entonces una especie de "nada" ante lo absoluto divino. Esta concepción basada en un pesimismo antropológico que caracterizará a la cultura pentecostal, debe ser entendida a la luz del contexto social e histórico que acompañó al crecimiento del pentecostalismo entre los sectores más pobres y desaventajados de Chile y América Latina. En este escenario, el hombre como patrón, padre, esposo o hijo, era capaz de transformar su hogar, el lugar de trabajo, la calle o la iglesia, en un espacio infernal, donde el dolor, la desesperanza y el vacío deshumanizaban al ser humano, sea como dominado o como dominador. El hombre era dominado en el trabajo y dominador en el hogar.

En la evidencia empírica existente se pueden apreciar muchos testimonios que señalaban que el alcohol y la violencia transformaban a los hogares en verdaderos infiernos terrenales. Los hombres golpeaban a sus mujeres e hijos y muchas veces abandonaban a sus familias. Gran parte del escaso dinero recaudado en trabajos que en muchas ocasiones eran miserables, era utilizado para costear el consumo de bebidas alcohólicas en cantinas y bares. En este contexto, los seres queridos se constituían en desconocidos o enemigos, seres derrotados que vivían en la miseria. Quizás lo peor fue que esta realidad se constituía en una prolongación que parecía reproducir el contexto familiar y social, pues los hijos varones normalmente solían repetir estas prácticas de sus padres, avalados socialmente por el supuesto cultural de que este parecía ser el destino de todo hombre.

Por otro lado, muchos patrones explotaban y oprimían a sus trabajadores, remunerándolos con sueldos de hambre. Además, normalmente podían existir bares y tabernas en los mismos espacios laborales, donde el trabajador concurría a "ahogar" sus penas laborales en alcohol. Para hacer rendir más al trabajador se utilizaba la figura del capataz, un compañero que solía ser descrito por el resto de los trabajadores como deshumanizado y que contaba con la confianza del patrón, además de poseer la fusta en mano para incentivar la producción. Refiriéndose a este escenario, el escritor Volodia Teitelboim señalaba que, de esta forma, "los hacendados gobernaban el país a sus antojo: mucho trago y poco trigo" ${ }^{19}$. No obstante, no debemos asociar el consumo del alcohol solo a las capas más pobres, obreros y proletariados de Chile, donde el pentecostalismo recogió a gran parte de sus fieles, sino también a la clase media chilena ${ }^{20}$, de manera que la imagen infernal construida por el pentecostalismo en torno al alcoholismo y el consumo de alcohol en general era extensiva a gran parte de la sociedad. Incluida la Iglesia Católica, pues en la celebración de las misas y una serie de otras celebraciones se bebía vino, simbolizando con ello la sangre de Cristo derramada en la cruz, transformándolo así en una bebida que redime al pecador. Aunque para los pentecostales se trataba de un brebaje infernal que arrastraría a los disolutos a la muerte.

Por lo tanto, otra forma de deslegitimar la competencia religiosa del catolicismo fue sostener que esta iglesia sacralizaba el alcohol en las misas, incentivaba el alcoholismo a través de las festividades santorales, y por último, lo transformaba en un negocio al solicitar los diezmos de todo el alcohol que se vendía en los alrededores del templo católico durante las festividades. Por ello el pentecostalismo concebía a los ritos y festividades católicas como espacios infernales. Aunque es llamativo que en las visiones e imágenes infernales construidas por los pentecostales no hubiese

Teitelboim 2010, 103.

Teitelboim 2002, 159. 
sacerdotes católicos, sino borrachos, pues en última instancia gran parte de la responsabilidad caía en el individuo y solo en menor medida en las instituciones.

Llegados a este punto, podemos apreciar que si bien en términos generales las imágenes dantescas del infierno cumplían funciones diversas, se destaca especialmente la función disuasiva de este simbolismo. Al parecer, la construcción simbólica del averno como un lugar bañado de fuego, oscuridad y sufrimiento, permitiría disuadir de realizar cualquier acto pecaminoso o práctica asociada a algún vicio. En este contexto, la descripción siempre contextualizada de estas imágenes solía estar dirigida a determinados actores sociales ubicados en los márgenes de la sociedad, o a seres descarriados de la religión pentecostal, a quiénes esta figura parecía hacerles más sentido, en tanto proyección o exacerbación simbólica de las condiciones sociales infernales en las cuales vivían, especialmente antes de la conversión.

De hecho, tanto los borrachos como los taberneros solían ser objeto de discursos que, por un lado, estaban cargados de mensajes con un claro sentido deontológico, y por otro lado, reafirmaban consecuentemente la descripción maligna del infierno y sus consecuencias. Según los pentecostales, tanto el borracho como el tabernero sufren de una eterna y viciosa sed, donde cada vez que llenan una copa de alcohol y la alzan para beberla, la bebida se transforma en un líquido de fuego que solo sirve para alimentar esta sed eterna. Tanto el bebedor como el expendedor son castigados así por su vicio. Obviamente, esta imagen del alcohol y sus horrores opera como un gatillante simbólico que desincentivaría al converso que buscara este vicio, asociándolo, a su vez, a su vida anterior vinculada normalmente al catolicismo.

\section{El miedo al Diablo}

Para construir la figura del diablo el pentecostalismo tomó imágenes de la Biblia, del catolicismo popular, del mundo campesino y del mundo indígena, generando finalmente una imagen ubicua, ambigua y poderosa de esta deidad ${ }^{21}$. Por un lado, los pentecostales creen, recrean e imaginan un sinnúmero de recursos simbólicos que los hace infatigables y más poderosos que el mismo Satanás. De hecho, existe la creencia de que Jesús es todo poderoso y venció al Diablo con su sacrificio mortuorio y su resurrección; por tanto, con el simple hecho de que los pentecostales invoquen el nombre de Jesús, el Diablo y sus secuaces huyen despavoridos. De esta manera el nombre de Jesús se constituyó en un conjuro. Por otro lado, también se encuentran los ángeles, quienes igualmente están al servicio guardián, protector y defensor de los creyentes. Estos seres alados siempre serán superiores a los demonios, por lo que estos últimos finalmente están condenados a huir ante su presencia. Finalmente, también existe el poder exorcizador que poseen los pentecostales, quienes con la ayuda del Espíritu Santo pueden expeler toda presencia diabólica de cuerpos, espacios y tiempos que conciban como sagrados.

No obstante, al Diablo se le atribuye un poder inaudito frente al descarriado pentecostal. Un descarriado es un individuo auto-excluido de la comunidad religiosa y

21 Aquí es interesante el trabajo de Manuela Cantón realizado sobre el pentecostalismo en Guatemala, donde destaca que "Satanás se erige como la figura capaz de articular el desvalimiento del indivuduo y la crisis socio-económica y política de Guatemala, que registra uno de los índices de pobreza, criminalidad, corrupción política e impunidad más altos de toda América Latina”. Cantón 2009. 
proclive a los males sociales que eran inducidos y gobernados por el demonio. Pero su potencial vínculo con la iglesia y su participación comunitaria no se estimulaban principalmente evocando las bondades del cielo, sino recordando el poder arbitrario del demonio. Si bien los pentecostales se auto-consideraban esencialmente excluidos de todo tipo de poder inmanente, también es cierto que empoderaban simbólicamente a sus conversos y creyentes, invistiéndolos del poder exorcizador y arrebozándolos de poderes invisibles. Por tanto, la magnificación del miedo al diablo significaba también incentivar la búsqueda del poder simbólico de los creyentes a través de la adquisición del carisma y la vinculación comunitaria, una clara forma de empoderamiento simbólico y social frente a los males sociales y culturales del entorno.

Debemos recordar que el Diablo es concebido como una divinidad maligna vencida, pero que poseía territorios y licencias morales muy significativas que eran difíciles de conocer y distinguir. Así, el Diablo es considerado como un dios báquico, un demonio que induce a los hombres, entre otras cosas, a beber vino y gastarse el dinero ganado en el trabajo y dedicado normalmente a la familia. Esta concepción del demonio parecía ayudar a los hombres que día a día llevaban en sus hombros el peso de su vicio. En esta situación, los efectos del síndrome de abstención del alcohol normalmente se consideraban como parte de una batalla que el espíritu humano sostenía con el mismísimo demonio, sembrando constantemente en la persona el deseo incontrolable de beber y el engaño de que su consumo no otorgaba mal alguno. Esta batalla, que parecía perdida para muchos católicos, estaba asegurada para los pentecostales, que si bien es cierto no conseguían una victoria sencilla ni fácil, si la alcanzaban con la ayuda del Espíritu Santo y la comunidad.

E1 Diablo también atacaba externamente con la tentación de las amistades y compañeros de trabajo que indiciaban, manipulaban y presionaban a los hombres neófitos a beber. De esta manera, tanto el deseo como la presión social se interpretan como una estratagema diabólica, lo cual aliviaba la carga de responsabilidad que poseían los hombres respecto a su vicio. Cuando los hombres reincidían en el consumo de bebidas alcohólicas, también había un aliciente que los ayudaba a disminuir su responsabilidad, haciéndole más fácil su regreso a la comunidad y su reinserción religiosa. Aunque debían asumir la debilidad humana, en última instancia era el Diablo quien tenía la culpa por inducirlos a beber. De manera que tanto el síndrome de abstinencia como la caída, la culpabilidad y la vergüenza eran obras de Satanás, reduciendo la responsabilidad individual al mínimo. El mal era ubicuo, gobernaba la subjetividad y las instituciones sociales. Incluso las mismas comunidades pentecostales eran proclives al mal. ¿Por qué? Quizás porque en la cultura pentecostal se concibe al mal como intrínseco a la humanidad. Allí donde hay seres humanos está también el mal. Pero también ahí donde hay dos o tres reunidos en el nombre de Jesús, está la posibilidad de construir una comunidad pentecostal. Por lo tanto, dicha comunidad existe para resistir y triunfar sobre el mal, aunque sea parcialmente, porque la comunidad siempre está amenazada interna y externamente: la fragilidad es su condición.

En general, en la cultura pentecostal las mujeres son concebidas como seres más fuertes que los hombres a la hora de soportar las influencias diabólicas relacionadas con el alcoholismo y la violencia ${ }^{22}$. No obstante, son concebidas especialmente débiles ante aquellas tentaciones vinculadas con el cuidado del cuerpo, donde las estrate-

$22 \quad$ Mansilla 2016. 
gias de embellecimiento y las tácticas de sensualidad solían ser vistas como prácticas y ritos utilizados por el demonio para engañarlas. De todas formas, la mujer es concebida como un ser fuerte. Sin embargo, cuando se trata de exculpaciones entre hombres y mujeres, la mujer es la que lleva el mayor peso de la culpa, mientras que los varones se ven relativamente exculpados de su responsabilidad. De igual modo, los testimonios señalan que son las mujeres las que realmente guerreaban con el Diablo para arrancarles de sus garras a sus maridos e hijos varones, liberándolos del vicio del alcohol y de las malas amistades. Vemos entonces que la relación simbólica entre el demonio y las mujeres no deja de ser paradójica.

Este fenómeno de culpabilización del Diablo y victimización de la masculinidad puede apreciarse en algunas anécdotas que circulaban dentro del movimiento pentecostal y que se hicieron muy conocidas en este circuito. Como la siguiente:

Se contaba que fuera de un templo pentecostal había una persona llorando. Entonces se le acercó un pentecostal y le preguntó: ‘¿por qué lloras?’ Ante lo cual el señor respondió: 'lloro porque todo me lo culpan a mí, cuando muchas de esas cosas ni siquiera he pensado en hacerlas'. El pentecostal preguntó entonces: ¿¿quiénes te culpan?'. El señor respondió: 'los evangélicos, siempre me culpan a mí'. El pentecostal preguntó finalmente: ‘¿Y quién eres tú?’ El desconocido lloroso respondió: 'yo soy el Diablo'.

Esta conocida anécdota que aún circula en los círculos pentecostales refleja de manera clara la paradójica relación establecida entre el diablo y los pentecostales. Por un lado, estos últimos aparecen como seres que engrandecen el poderío maligno de Satanás, mientras que por otro lado, reducen su responsabilidad personal frente a aquellos hechos donde el maligno ha intervenido. Si bien con el paso del tiempo la cultura pentecostal comenzó a intensificar la figura de la responsabilidad en sus creyentes, nunca abandonó aquella descripción extremadamente poderosa y maligna de Satanás, en torno a la cual se ha cultivado la figura del miedo pentecostal. De hecho, la figura de Satanás sigue siendo absolutamente clave en el ideario pentecostal.

En este punto también debemos recordar que el pentecostalismo, muy lejos de ignorar y abstraerse de la sociedad real, ha construido una imagen que refleja muchos de sus aspectos, incluso los más repulsivos, como la crudeza del poderío del mal que rodea a los pobres, marginales, indígenas, obreros y campesinos. De esta forma, esta figura demoníaca aparece configurándose en función del desarrollo histórico del movimiento y de la sociedad en su entorno ${ }^{23}$, perdiendo cierto grado de responsabilidad en algunas acciones pecaminosas de sus creyentes, dada la creciente autonomía e individualización que estos últimos adquirían. Sin embargo, siguió encarnando una figura que suscita el temor en los creyentes.

\section{EI miedo a Dios}

Si la prédica pentecostal para incentivar la conversión se sustentó en los afectos, la prédica para retener a sus conversos en el seno de la iglesia comulgó expresamente con el miedo. La evidencia empírica y bibliográfica muestra que la distinción

\footnotetext{
23 Orellana 2013.
} 
amor/miedo fue una de las diadas simbólicas más significativas que acompañó al desarrollo del pentecostalismo en Chile hasta la década de los 80. En el contexto de la prédica del amor, se sostenía y enfatizaba de manera incansable la siguiente cita bíblica: "lo vil del mundo y lo menospreciado escogió Dios, y lo que no es, para deshacer lo que es". Al parecer, este principio estaba dirigido a los condenados y desheredados de la tierra, según la expresión de Fanon ${ }^{24}$, quienes se veían efectivamente atraídos por esta interpelación, siendo consolados y fortalecidos en los templos pentecostales por el determinismo providencialista brindado por estas comunidades $^{25}$.

El simbolismo que representa a Dios resulta complejo, pues si bien en los discursos aparecía la metáfora que señalaba "Dios es amor", también aparecía muy claramente que Dios podía ser "fuego consumidor". En la última expresión, la dimensión omnipotente de un Dios castigador aparece claramente magnificada y asociada a un elemento típico de la tradición bíblica (fuego), haciendo patente así la otra cara del buen $\operatorname{Dios}^{26}$.

Esta lectura encuentra tierra fértil en un contexto social, político, económico y cultural propio que caracteriza a América Latina. Sociedades marcadas por la opresión y la explotación, donde instituciones como la familia, la religión, la escuela y el trabajo ejercían el castigo, y de manera especial con los pobres, marginales e indígenas. No resultaba extraño que dichas predicaciones fueran perfectamente verosímiles y admisibles, donde si bien la imagen Dios aparecía como una extensión trascendente, era isomorfa de la sociedad chilena y latinoamericana.

¿Cómo se entiende esta dualidad de lo trascendente (castigo/amor)? Siguiendo la tradición sociológica durkheimiana, y alejándonos de la interpretación teológica, esta comprensión de Dios puede ser interpretada en diálogo con el contexto social. Para ello debemos recordar que gran parte de las sociedades latinoamericanas fueron sociedad del castigo, especialmente con los más pobres e indígenas. Esto va más allá de las instituciones del castigo destacadas por autores ya clásicos. Se trata de instituciones como la escuela, la iglesia y la familia, y que poseen una condición dual: son instituciones afectivas y coercitivas, castigadoras y premiadoras a la vez, donde no se podía separar el afecto del castigo, pues eran simultáneamente protectoras y opresoras. Estas relaciones dialécticas se establecían también entre Dios y la sociedad, retro-proyectándose mutuamente y trascendentalizando el castigo. Sin embargo, dado que la imagen de este último estaba dirigida a los pobres de la sociedad, se fomentaba con ello el aprendizaje del sometimiento ante el poder en general y la sumisión ante la figura de los ideólogos de las instituciones, quienes detentaban el poder económico, político y social.

La idea de Dios como fuego consumidor también posee una semejanza con la imagen represora del Estado. Hasta fines de la década de 1980, Chile fue víctima de una dictadura militar que convirtió al país en una tierra donde el fuego era una realidad para quienes reclamaban sus derechos (humanos, laborales, etc.). Si nos retrotraemos a la primera década del siglo XX, justamente cuando nació el pentecostalismo chileno (1909), podemos apreciar que Chile era un país donde la muerte era un

24 Fanon 2007.

25 Este determinismo providencialista puede entenderse a partir de la consigna bíblica que señala que "Jehová es mi Pastor y nada me faltará" (Salmo 23).

26 Como destaca Thomas, "el fuego es a la vez devorador, destructor y purificador por excelencia" Thomas 1983, 55 . 
hecho fatídico recurrente entre los obreros del salitre: la matanza de la Plaza Colón en Antofagasta (1906), la matanza de la Escuela de Santa María (1907), o la matanza de la Coruña (1925), son claras evidencias de ello, además de la muertes producidas por las malas condiciones laborales de los obreros del carbón. Estos hechos históricos son importantes a nivel social, pues fue a estos obreros a quienes el pentecostalismo dirigió sus predicaciones, y quizás por ello también los pentecostales asociaron real y simbólicamente el trabajo y la muerte.

El ethos obrero marcó con fuego al incipiente pentecostalismo, manifestándose, por ejemplo, en la reconsideración del rol del pastor como un trabajo religioso. El líder pentecostal se identificó con un obrero y una de las mayores ofensas que se podían levantar contra él era acusarlo de jefe o patrón. La vinculación de cualquier creyente con un templo pentecostal también debía pasar por la figura de la labor o el trabajo obrero. Ser "obrero del Señor", "obrero cristiano", "sufrir como obrero", "vivir como obrero" o "morir como obrero", eran metáforas que no solo simbolizaban la honra que producía a los creyentes su adscripción religiosa dentro de los círculos pentecostales, también daban cuenta del tipo de imaginario que se construyó en torno a los pentecostales, fuertemente impregnado de la cultura del trabajo obrero y, por lo tanto, influenciado por las condiciones sociales. Si la fábrica se constituyó muchas veces en un espacio sepulcral para los pentecostales, el templo fue concebido como un espacio redentor.

El "temor a Dios", aquella relación de comunión con lo trascendente bañada por los sentimientos de afectos filiales y fraternos, también permite marcar claramente aquella insondable diferencia ontológica entre Dios y el creyente. Aquí la relación entre lo trascendente y lo inmanente, lo espiritual y lo social, es gobernada por el miedo. La consigna parecía clara: a Dios no solo había que amarle, sino también temerle. Así, en el pentecostalismo pareciera seguirse aquella matriz de tradición veterotestamentaria donde la figura de Dios aparece dibujada como un padre castigador que, más que alegrarse por el bien, se enfurecía cada vez que el mal afloraba entre sus fieles.

En el contexto latinoamericano esta idea no era solo parte de la realidad pentecostal, sino que se trataba de una herencia católica muy presente. Si nos retrotraemos al imaginario popular reciente, podemos advertir cómo los niños eran educados y socializados bajo la idea de la existencia de la mirada vigilante de un Dios que poseía el don de la ubicuidad y que, sobre todo, era castigador ${ }^{27}$. Una idea genérica como esta, que puede ser advertida en gran parte de las doctrinas cristianas, era leída de manera contextual en el caso chileno y se manifestaba de manera concreta en diversas prácticas propias del pentecostalismo.

Es común encontrar testimonios donde se señala la existencia de reuniones pentecostales en las cuales las personas caían bajo el éxtasis del Espíritu Santo, confesaban sus pecados públicamente y comenzaban un proceso de evidente catarsis, llorando de miedo y arrepentimiento. En otras oportunidades, se levantaba "un instrumento de Dios" (creyente) y con ritmos extáticos se dirigía hacia una persona, ponía impetuosamente sus manos sobre ella y decía fervorosamente: "tienes que confesar tu pecado". En instantes como estos, aquellas personas aparecían descubiertas ante los asistentes y confesaban sus pecados; otras, ante el terrible miedo de

27 Dichos como populares como: "no hagas esto porque Dios te está mirando", o "no hagas esto otro porque Dios te va a castigar", reflejan esta situación. 
ser descubiertas, también hacían lo propio. Para entender una escenificación ritual como esta es clave comprender el rol que juega la figura del miedo a Dios en la cultura pentecostal. Si hay algo que Dios odia más profundamente que el pecado, esto es el pecado oculto. Ante un hecho como este, Dios, gracias a su infinito poder, podía escoger retirarse de la presencia del creyente, permitiendo así que el ser más maligno de la existencia, el Diablo, penetrara y poseyera al pecador, provocándole cualquier enfermedad. De esta forma, la figura del miedo a Dios se ve duplicada simbólicamente, motivando así dejar atrás la opacidad del pecado personal.

En este sentido, el pentecostalismo representa parcialmente la otra cara de la cultura religiosa de la modernidad. Es la religión del vencido, del colonizado, del ensangrentado, del castigado. Por ello se resalta el simbolismo del castigo y del miedo, pues se aprende con sangre, miedo y fuego. Así, la religión es concordante con las condiciones de vida sufriente de los pobres. Es casi inverosímil que el pentecostalismo muestre a una divinidad que, pese a que sus creyentes le sirvan, le atiendan y sigan las reglas al pie de la letra, se conforme con ello. Al parecer, ningún esfuerzo es suficiente. Siempre está presto a castigar el más mínimo error. Es la representación de una deidad que no tiende a centrar su atención en lo bueno del ser humano y el mundo, sino en la menudencia de las faltas que luego son transformados en grandiosos horrores y castigados sin demasiada condescendencia.

¿Por qué el pentecostalismo ha esculpido la imagen de una divinidad tan azotadora? ¿Por qué el Dios pentecostal está dispuesto a castigar en el cadalso hasta el más mínimo error? En este escenario es importante destacar que muchos de los ritos celebrados por los pentecostales, como las reuniones de Santas Cenas, Vigilias u oraciones para enfermos, se transformaban también en ceremonias pertinentes para la confesión de los pecados, motivados por el temor a Dios. Por ejemplo, supongamos que alguien estaba en medio de la congregación con un pecado oculto, religiosamente denominado "el pecado de Acan". En este escenario, el creyente y la comunidad entera sabían que si el pecado no era revelado, Dios no sólo consumiría al pecador, sino también a toda su familia. Por lo tanto, quien confesaba era proclive a la misericordia divina y congregacional. Pero de este temor a Dios, motor último de la práctica de develamiento, se pasaba al padecimiento del castigo social y público ejercido por la congregación, pues quienes confesaban eran castigados con un año de disciplina, continuando así el tortuoso camino del temor. En concreto, el pecador confeso debía trasladarse durante todas las ceremonias del año al "asiento de la ignominia", es decir, a la última banca disponible del templo. Además, constantemente debía pasar al altar a suplicar por la misericordia de su Dios castigador, quien en su infinita potestad le habría librado parcialmente del pecado, pero dispensándole siempre un castigo. También debía suplicar por el ostracismo de la hermandad, la cual dictaminaba y ejercía el castigo. Tampoco podía acceder al rito (sacrificial) de la Santa Cena, hasta que no se cumpliera la sanción y el hermano o hermana haya soportado ascéticamente el castigo, siendo reintegrado así a la comunidad como alguien restaurado.

La imagen social de Dios también posee un símil con las instituciones donde suele cultivarse la esperanza social, especialmente en la escuela. Aquí encontramos la distinción entre castigo y premio, traducida socialmente como la distinción entre los elegidos y los expulsados, ambas cargadas de un claro simbolismo sagrado. En un escenario histórico donde crecientemente diversos grupos sociales defienden e impulsan el desarrollo y la expansión de la educación como símbolo de progreso y civiliza- 
ción, la escuela es una institución dibujada en un horizonte utópico, pues encarna y promulga la promesa de una sociedad y un mundo mejor. Pero al igual como ocurre en muchos ritos de paso de diversas sociedades, esta promesa simbólica llevará aparejada un tránsito cargado de sacrificios, traducidos muchas veces en castigos. De hecho, en las escuelas se ejercía un sin número de castigos físicos, sociales y simbólicos, entre los cuales se encontraban los golpes, las malas calificaciones (notas), las anotaciones personales en el libro de comportamiento, e incluso las expulsiones, las que finalmente daban pie a que los infractores fueran borrados del libro de la escuela. De manera homóloga, en el pentecostalismo el peor miedo lo encarnaba el potencial hecho de ser "borrado del libro de la vida" de manera indefectible.

Si visitamos nuevamente el imaginario popular de la cultura pentecostal, podemos apreciar que está lleno de relatos donde se evidencia el temor a Dios. Muchos de ellos obedecen a testimonios personales, donde el temor se expresa muy intensamente. Pero también nos encontramos con sabrosos relatos, basados o no en la realidad, que igualmente nos recuerdan aquél temor omnipresente en los corazones pentecostales. Por ejemplo, una de las prácticas más denostadas dentro de la comunidad pentecostal es quedarse dormido en las vigilias, pues no solo son sinónimo de falta de espiritualidad, sino que evidenciaba también la debilidad carnal, convirtiéndose así en una práctica digna del castigo divino. Al respecto, popularmente se cuenta una conocida anécdota ocurrida supuestamente en una vigilia:

Un hermano trabajó durante todo el día en la construcción [obrero]. A pesar del cansancio, fue a la vigilia y se quedó dormido. De pronto se despertó y, al ver todo oscuro y escuchar solo el canto de sus hermanos, se puso a gritar en medio del culto diciendo: ‘¡Dios perdóname, nunca más me voy a quedar dormido, pero devuélveme la vista!, iperdóname que soy un pecador!'. Entonces, un hermano de al lado le dijo: 'hermano, usted no está ciego, lo que pasa es que simplemente se cortó la luz'.

Si uno echa un primer vistazo a este testimonio, no puede evitar encontrar una escena tragicómica. No obstante, pese a la tranquilidad que tuvo el hermano después del incidente, el testimonio continúa relatando que no faltó quien se acercó a su lado y le señaló que lo ocurrido era claramente "una señal divina". Las manifestaciones de Dios son misteriosas, de manera que una humorada bien puede ser leída como un mensaje que posee una segunda lectura, sobre todo considerando el enorme poder de Dios y su ubicuidad, dignos de cualquier temor. De esta forma, el miedo se vuelve a reintroducir en los creyentes, no pudiendo escapar de él ni siquiera en situaciones como la señalada.

\section{Reflexiones finales}

Hemos intentado describir y analizar algunas de las manifestaciones más importantes del simbolismo del miedo en la cultura pentecostal, tomando como referencia el caso chileno. Hemos podido apreciar que el miedo operaría como uno de los símbolos dominantes ${ }^{28}$ del pentecostalismo, manifestándose ampliamente en diversos dis-

28 Turner 1973. 
positivos discursivos (como testimonios, relatos, etc.) y articulando en torno a él una serie de significados que pueden tornarse paradójicos.

Hemos podido advertir cómo el miedo se ha manifestado de manera concreta en la cultura pentecostal en las figuras del infierno, el Diablo y Dios. Su alta predominancia en los diversos dispositivos discursivos evidencia que se trató de un figura gravitante dentro de la simbólica pentecostal, tanto a nivel doctrinario como práctico, evidenciando que una de las peculiaridades del miedo es que suscitaba de manera especial la atención de los creyentes.

También apreciamos que la tríada simbólica analizada (infierno-Diablo-Dios) posee un alto grado de polisemia. En este sentido, podemos ver que las figuras del infierno, el Diablo y Dios, no poseen sentidos meramente unívocos ni pueden reducirse meramente a características positivas o negativas, como normalmente se suele atribuir de manera simplista al pentecostalismo. Estas figuras simbólicas evocan interpretaciones muy disímiles y que pueden tornarse incluso paradójicas. Esto último ha permitido que, por ejemplo, pueda convivir la figura de un Dios bondadoso con la figura de un Dios castigador, permitiendo a su vez que el miedo pueda aparecer asociado a la divinidad mayor, pese (o debido a) su polisemia. De manera similar ocurre con las otras manifestaciones simbólicas y con la diada Dios/Diablo.

Gracias a esta capacidad polisémica y paradójica que poseen las figuras simbólicas donde se manifiesta el miedo, han podido ser utilizadas (consciente o inconscientemente) como vehículos con una función disuasiva. En concreto, la reconstrucción del miedo tiende a poseer un claro sentido deontológico y pedagógico, a partir del cual se comunica a los creyentes o futuros creyentes una matriz sociocultural específica que se nutre del contexto histórico, social y cultural. Esto permite orientar la acción pentecostal en la vida terrena, siempre alejada del pecado y apegada al camino de Dios. Así, la figura del miedo posee siempre un carácter aleccionador, el cual, gracias a sus soportes simbólicos, puede manifestarse de muy variadas maneras, facilitando con ello la comprensión de su sentido por parte de los creyentes.

Esta vinculación estrecha entre la semántica del miedo y sus soportes simbólicos por un lado, y las condiciones históricas, sociales y culturales que han acompañado el desarrollo del pentecostalismo en Latinoamérica, por otro lado; nos muestra cómo la figura del miedo emerge como una verdadera bisagra simbólica que estable puentes interpretativos con la dimensiones histórica, social y cultural. Ambos lados de esta distinción aparecen replicados y retroproyectados mutuamente, aunque sea de manera parcial y fragmentaria. Consideramos que esto nos ofrece un fecundo ámbito de trabajo, especialmente si queremos comprender realmente cuál es el trasfondo sociocultural de la figura del miedo en el pentecostalismo y cuáles son sus nuevas manifestaciones específicas, las cuales esperamos seguir investigando en el futuro.

De todas formas, consideramos que es necesario entregar una breve observación final sobre la actualidad de estos miedos en el pentecostalismo y la emergencia de nuevas figuras socioculturales que han están siendo repositorios de esta nueva semántica del miedo.

En primer lugar, debemos señalar que si bien el miedo al infierno, al Diablo y a Dios sigue estando presente en el pentecostalismo, ha disminuido su intensidad y se ha transformado esta imagen en los últimos años. Tanto las nuevas generaciones de conversos como de predicadores, ya no predican predominantemente sobre miedos metafísicos. Sin embargo, utilizan miedos concretos y actuales como la delincuencia, el desempleo, la vejez, la soledad o la corrupción, donde el Diablo ya no es 
siempre el principal responsable. De manera que si bien los miedos metafísicos han disminuido, ha quedo una clara herencia de los miedos terrenales que azotaban al pentecostalismo temprano.

En este nuevo escenario, se destaca el miedo a la política, el cual no está asociado necesariamente con la denominada huelga política destacada por D'Epinay ${ }^{29}$, sino más con el miedo a la protesta contra la desigualdad social, la explotación y la discriminación de las minorías (indígenas o inmigrantes). En este sentido, sigue existiendo un miedo soterrado hacia el patrón y el Estado, desincentivando con ello que sus jóvenes participen en organizaciones políticas ${ }^{30}$. También se destaca el miedo al liderazgo femenino dentro del pentecostalismo. Las mujeres han cumplido un rol central en este movimiento como predicadoras de la calle, evangelizadoras, sanadoras, Dorcas o pastoras ${ }^{31}$. Sin embargo, se ha recreado una serie de creencias y restricciones que las han mantenido en un constante estado de control social y sumisión respecto a los hombres; generando una serie de títulos honoríficos de apóstol, profetas, conferencistas internacionales, etc., que realmente impiden que las mujeres accedan a estos liderazgos.

En este nuevo contexto, la semántica del miedo pareciera estar nuevamente reconfigurándose en una sociedad crecientemente democrática, pero quizás no con el ritmo necesario. Es de esperar entonces que el pentecostalismo pueda leer de manera contextual el nuevo escenario social en Chile y Latinoamérica, entregando una respuesta que esté en sintonía con los desafíos actuales.

\section{Bibliografía}

\subsection{Fuentes primarias}

Revista Chile Pentecostal, Año I, N 3. Diciembre, 18 de 1910. Concepción.

Revista Fuego de Pentecostés 1927- 2016. Iglesia Evangélica Pentecostal de Chile, Santiago.

\subsection{Fuentes secundarias}

Bahamondes, L. y Marín, N., "Miedos sociales y religión: una reflexión a partir del pentecostalismo urbano chileno". Sociológica, 28(78) (2013), 99-138.

Bunge, M., "El efecto San Mateo". Polis, 2, (2002) s/p.

Cantón, M., "Simbólica y política del Diablo pentecostal". En: Cultura y Religión, Universidad Arturo Prat, Vol. 3, N 1 , (2009) 81-94.

Cleary, E. \& Sepúlveda, J., "Chilean Pentecostalism: Coming of Age". En: Edward, Cleary \& Hannah, Stewart-Gambino (Eds.) Power, Politics, and Pentecostals in Latin America. Colorado: Westview Press, (1997) 97-122.

Delumeuau J., El miedo en Occidente. Madrid: Taurus, 2005.

D'Epinay, C. L., El refugio de las masas. Estudio sociológico del protestantismo chileno. Santiago: Universidad de Santiago de Chile - Instituto de Estudios Avanzado USACH Centro Evangélico de Estudios Pentecostales CEEP, 1968.

\footnotetext{
D'Epinay 1968.

Parker y Fediakova, 2009

Orellana, 2009; Mansilla y Orellana, 2012; 2014
} 
Fanon, F., Los Condenados de la Tierra. México: Fondo de Cultura Económica, 2007

Mansilla, M., “¿La caja del Diablo? Los miedos a la secularización del pentecostalismo chileno". XXVII Congreso de la Asociación Latinoamericana de Sociología. Buenos aires: Asociación Latinoamericana de Sociología, 2005

Mansilla, M., "Miedo, control y disuasión en el pentecostalismo chileno. Las representaciones del Infierno en la Iglesia Evangélica Pentecostal de Chile entre 1928-1950". En: M. Mansilla. (2007) Despreciados y desechados. Itinerario de la canutofobia en Chile en la primera mitad del siglo XX. Cultura y Religión, 1(2), (2013) 1-18.

Mansilla, M., "Cuando el Diablo anda suelto: Las representaciones del mal en el pentecostalismo chileno, 1909-1938”, En: Voces del Pentecostalismo Latinoamericano III. Identidad, teología, historia, RELEP, Concepción, 2009.

Mansilla, M., "Miedo, control y disuasión en el pentecostalismo chileno. Las representaciones del infierno en la Iglesia Evangélica Pentecostal de Chile, 1928-1950". C. Mondragón y C. Olivier. (coords.). Minorías religiosas: el protestantismo en América Latina. México: Centro de Investigaciones sobre América Latina y el Caribe (CIALC) - UNAM, (2014) 147-174.

Mansilla, M., La buena muerte. La cultura del morir en el pentecostalismo. RIL- UNAP, Santiago, Chile, (2016).

Marín, N., "La representación social del Diablo en el Pentecostalismo: Un estudio de caso en Santiago de Chile". Cultura y Religión, Vol. IV, № 2, (2010) 225 - 240.

Merton, R., "The Matthew Effect en Science. The reward and communication systemsof science are considered". Science, 159 (3810), (1968) 56-63.

Nietzsche, F., Ecce homo. Madrid: Alianza. 1976.

Piñuel, J., "Epistemología, metodología y técnicasdel análisis de contenido". En: Estudios de Sociolingüística 3(1), (2002) 1-42.

Orellana, F., "El diablo y su posicionamiento en la posmodernidad: una reflexión desde la teoría social". Universum, 28(2), (2013) 89-208.

Teitelboim, V., Hijo del Salitre. Santiago de Chile: LOM. 2002

Turner, V. "Símbolos en el ritual Ndembu". En: V. Turner Simbolismo y ritual. Lima: Pontificia Universidad Católica del Perú, (1973) 15-49. 